\title{
UTILIZATION OF SWINE DEEP BEDDING ASHES AND RICE HUSK IN
}

\section{CEMENTITIOUS COMPOSITES}

\author{
D. C. G. OLIVEIRA ${ }^{1 *}$ \\ H. SAVASTANO JUNIOR ${ }^{2}$
}

\begin{abstract}
The swine deep bedding is an alternative pig production, especially during the growing and finishing pig, whose product can be recycled, with reduced environmental impact. Usually the waste being used as fertilizer for crops, can alternatively be combusted and its ashes can be applied to materials based on cement. Therefore, the objective of this study was to evaluate the use of swine deep bedding ashes for replacement partial of Portland cement and rice husk its interaction through physical and mechanical characterization. Were prepared four sets of specimen: C1 - control (Portland cement and sand), C2 - control with $30 \%$ of SDBA, C3 - control with HR, C4 - control with 30\% SDBA and RH; the ashes replaced the Portland cement and rice husk the sand. According to the results of characterization, the composite with the addition of swine deep bedding ashes and rice husk can be used in rural constructions.
\end{abstract}

Keywords: rural construction, swine production, sustainability

\section{INTRODUCTION}

The Brazilian swine production has suffered severe criticism because of pollution, especially in the water, in regions of higher concentration animal, putting in question the production model currently adopted (HIGARASHI, 2008). The swine deep bedding (SDB) production system is an alternative in which the waste composition occurring on site (OLIVEIRA, 1999) in order to reduce the risk of pollution (air, water and soil) and have a better agronomic value.

In the search for alternative ways to use the SDB, this possibility that the burning and the generation of ashes, Di Campos (2008) studied the "deep bedding" based on rice husk as an alternative material for buildings seeking to identify the potential use of ashes as a mineral addition for partial replacement of Portland cement in cementitious materials. The use of ashes from the controlled burning of SDB based on the rice husks may contribute to the reduction of emission of $\mathrm{CO}_{2}$ in the air and release of ammonia $\left(\mathrm{NH}_{3}\right)$ in the soil, in order to reduce costs and aggregate value to the final product (OLIVEIRA, 2012). a practice used to reduce the impact of rice husk in landfills is its use as bedding for animals production or burning it for power generation in furnaces. the use of rice husk in nature as an alternative material in construction, replacing the sand, is used for low-income housing, which provide constructions equivalent to traditional constructions (MARTINEZ, 2003). 
The increasing demand for products with low environmental impact during its production process, application, use and post-use, combined with the reduction in consumption of primary materials, has established itself as a target for

\section{MATERIAL AND METHODS}

This study was conducted at the Faculty of Animal Science and Food Engineering, campus of University of São Paulo, located in Pirassununga, state of São Paulo, Brazil. It was conducted in two phases: preparation / curing of composites and determination of physical and mechanical properties. sustainable construction (LUZ, 2005). In this way the objective of this study was to evaluate the use of swine deep bedding ashes for replacement partial of Portland cement (PC) and rice husk its interaction through physical and mechanical characterization.

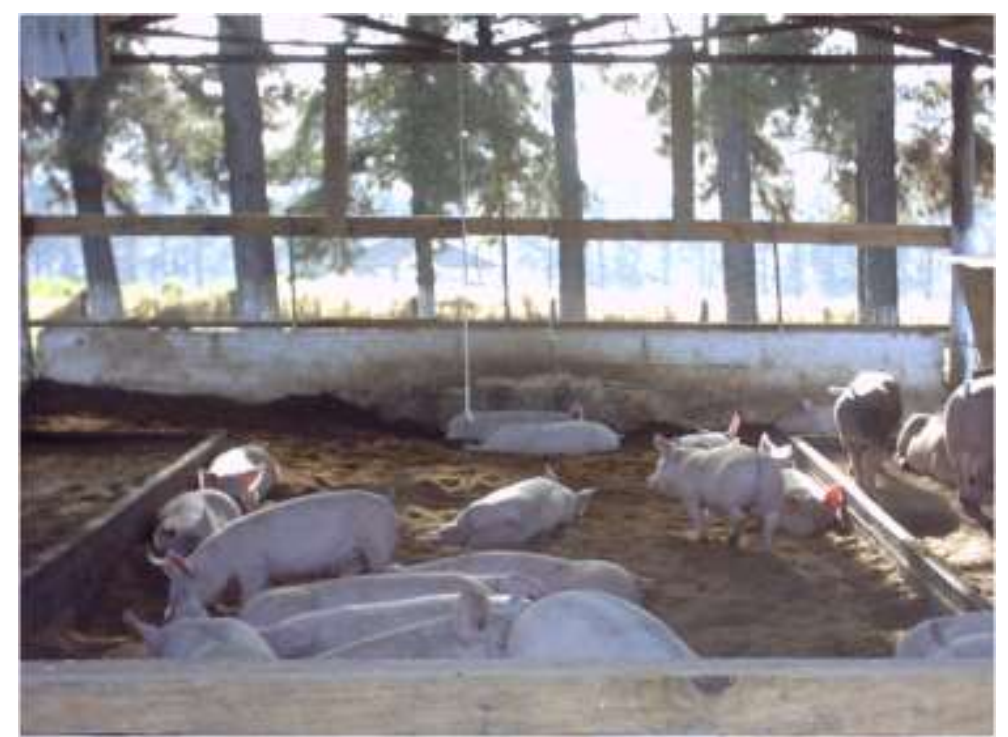

Figure 1 - Production system of swines in deep bedding

The SDB was initially burned in a muffle furnace (Jung brand / model 10010) with a heating ramp of 5 ${ }^{\circ} \mathrm{C} / \mathrm{min}$, at $600^{\circ} \mathrm{C}$ for $3 \mathrm{~h}$, and then cooled naturally. After burning and cooling process, these materials were placed in porcelain jar of $7.5 \mathrm{I}$ of volume, containing 32 balls $(24-26 \mathrm{~mm}$ diameter) at a speed of $200 \mathrm{rpm}$, in a rotary ball mill (trade Tecnal / model TE-500) for $240 \mathrm{~min}$, forming the swine deep bedding ashes (SDBA), as the
The swine deep bedding (SDB), based on rice husk used in the finishing phase of swine production (Figure 1). Samples were collected at random points of the installation, homogenized and packaged appropriately. 
order to acquire a better packaging, we sieve number 16 (0.19 $\mathrm{mm}$ opening). chose to use the bark retained on

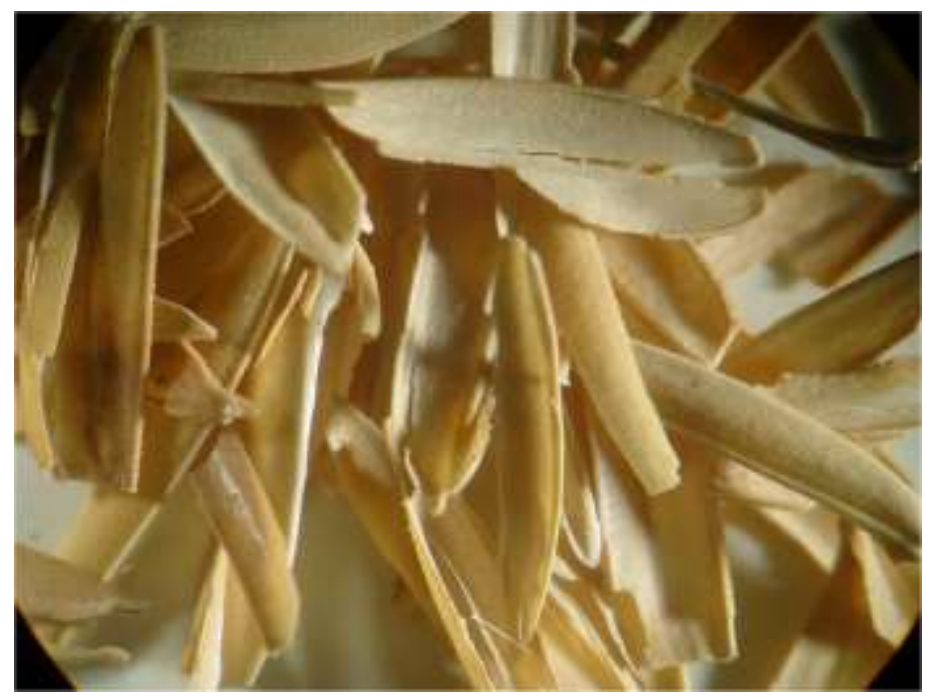

Figure 2 - Rice husk in natura

The mixture of these materials (Table 1) was done in a planetary mixer (Cairo Metal brand / model AG5) with a tank capacity of $5 \mathrm{~L}$, and low speed of $62 \pm 5 \mathrm{rpm}$. The materials (dry) were homogenized for $5 \mathrm{~min}$, then water was added slowly and the dough was in the mixer for 5 more min.

Table 1 - Formulation of cementitious composites (\% by dry mass).

\begin{tabular}{lllll}
\hline Raw material & C1 & C2 & C3 & C4 \\
\hline Ordinary Portland cement $^{\star *}$ & 25 & 17.5 & 17.5 & 25 \\
Sand & 75 & 75 & 71 & 71 \\
Rice husk & --- & -- & 4.0 & 4.0 \\
Swine deep bedding ashes & --- & 7.5 & --- & 7.5 \\
\hline \multicolumn{1}{c}{${ }^{*}$ Where the RH rep }
\end{tabular}
weight of cement. With water cement factor of $0.6(\mathrm{w} / \mathrm{c}=0.6) .{ }^{*}$ Ordinary Portland cement (OPC) type CP V-ARI, correspondent to ASTM-C150.

To prepare the specimes (square geometry), the mortar was poured in a wooden frame with metallic background with was compacted by vibration for $4 \mathrm{~min}$, using a vibrating table with flat surface, set in motion by a motor of $3 \mathrm{~kW}$ and with vibration frequency of $2200 \mathrm{rpm}$.

After the plates were molded, they were placed in a tray completely sealed with plastic for two days, and two plates were prepared for each formulation, with dimensions $200 \mathrm{~mm} x$ $200 \mathrm{~mm} \times 14 \mathrm{~mm}$. Then, curing was performed, in which plates was immersed in water for 26 days.
The plates of 28 days old were cut into circular saw cooled by water, with diamond disk, ensuring the integrity of the test specimens, used in the nominal dimension of $160 \mathrm{~mm} \times 40$ $\mathrm{mm} \times 14 \mathrm{~mm}$ and tested in saturated water condition, due to the curing process adopted; before the bending test the excess of water was removed from the surfaces of the plate with a cloth.

The mechanical tests were performed on a universal testing machine (EMIC brand / model DL30000), according to RILEM (1984). The mechanical properties were 
determined modulus of rupture (MOR), limit of proportionality (LOP), modulus of elasticity (MOE) and specific energy (SE), according to Tonoli (2007). Were evaluated in the physical tests (ASTM C-948-81): water absorption apparent

\section{RESULTS AND DISCUSSION}

The Table 2 shows the mean values (Tukey test, $P<0.05$ ) of the mechanical tests. The MOR is related to the tensile strength in bending and the maximum voltage is reached after the cracking / cracking of the specimen. The results clearly show
(WA), apparent density (AD) and apparent porosity (AP). For statistical analysis we used a completely randomized design and comparison of means the Tukey test at a confidence level of $95 \%(P<0.5)$.

that the composite reference (C1) having a value of MOR significantly higher than other composites. This difference indicates that the introduction of SDBA and rice husk produces defects in the microstructure of the composite.

Table 2 - Mean values of mechanical properties of composites.

\begin{tabular}{lcccc}
\hline Composites & LOP $(\mathrm{MPa})$ & $\mathrm{MOR}(\mathrm{MPa})$ & $\mathrm{MOE}(\mathrm{GPa})$ & $\mathrm{SE}\left(\mathrm{KJ} / \mathrm{m}^{2}\right)$ \\
\hline C1 (PC) & 4.65 & 5.26 & 14.66 & 0.04 \\
C2 (PC+SDBA) & 4.88 & 5.04 & 10.96 & 0.06 \\
C3 (PC+RH) & 3.81 & 3.83 & 6.95 & 0.09 \\
C4 (PC+SDBA+RH) & 3.37 & 3.46 & 5.40 & 0.11 \\
\hline
\end{tabular}
Tukey Test, $\mathrm{P}<0.05$.

The LOP is the maximum straining reached in flexure, before the composites leaving of the regime elastic. The decrease in the value LOP of composites $\mathrm{C} 3$ and $\mathrm{C} 4$ are related to the introduction of rice husk in the matrix composite.

The modulus of elasticity (MOE) is directly related to the stiffness of the composite. This property is directly related to the matrix of the composite. With this, the reference formulation $\mathrm{C} 1$ and $\mathrm{C} 2$ have a more rigid matrix of the other composites, with less critical defects, the introduction of rice husk in the matrix of the composite decreases the value of the MOE. It is noted that the composite rice husk ( $\mathrm{C} 3$ and $\mathrm{C} 4$ ) have a higher toughness compared to composites $\mathrm{C} 1$ and $\mathrm{C} 2$.

The specific energy (SE) is the ability to absorb impact energy and, therefore, is related to the toughness of the material, there is obtained a greater value in the C4. According to NBR 15498 (2007), the mechanical performance of plates with SDBA may be classified as Class A, Category 2 (4 $\mathrm{MPa}$ ). Thus, according to the characterizations made and standard mentioned, these composites may be used in farm buildings. The results of physical testing of composites are described in Table 3. 
Table 3 - Mean values of physical properties of the composites.

\begin{tabular}{|c|c|c|c|}
\hline Composites & WA & $A D$ & $\mathrm{AP}$ \\
\hline $\mathrm{C} 1(\mathrm{PC})$ & $10.14^{d}$ & $2.01^{a}$ & $20.41^{\mathrm{C}}$ \\
\hline $\mathrm{C} 2(\mathrm{PC}+\mathrm{SDBA})$ & $11.02^{\mathrm{C}}$ & $1.93^{\mathrm{b}}$ & $21.24^{b}$ \\
\hline $\mathrm{C} 3(\mathrm{PC}+\mathrm{RH})$ & $13.61^{\mathrm{b}}$ & $1.75^{\mathrm{c}}$ & $21.36^{\mathrm{b}}$ \\
\hline $\mathrm{C} 4(\mathrm{PC}+\mathrm{SDBA}+\mathrm{RH})$ & $15.22^{a}$ & $1.70^{\mathrm{c}}$ & $25.98^{a}$ \\
\hline
\end{tabular}

According to the Tukey test ( $P$ $<0.05)$, the composite containing ashes (C2) have a higher water absorption (WA) when compared with the composite reference without SDBA (C1). It is observed that the presence of rice husk increasing the value the WA. However, the apparent density (AD) composite reference, is

\section{CONCLUSION}

Through the results exposed in relation the physical and mechanical analysis, the composites studied, it was concluded that the swine deep bedding ashes contributed to improved

\section{ACKNOWLEDGEMENTS}

The Foundation for Research Support of the State of São Paulo (FAPESP) for granting the master's scholarship, the productivity

\section{REFERENCES}

ASTM C 948-81. Standard. Dry and wet bulk density, water absorption and apparent porosity of thin sections of glass-fiber reinforced concrete; 2009.

ASTM C150/C150M-11. Standard. Standard Specification for Portland Cement; 2011.

DI CAMPOS, M. S.; BARBOSA, N. P.; SAVASTANO JR., H. Swine deep bedding ashes as a mineral additive for cement based mortar. Scientia Agricola (Piracicaba, statistically superior to the others specimes, and this may be due to the incorporation of SDBA and rice husk in the composites. Regarding apparent porosity (AP) it is observed that the composite (C4) showed value a statistically superior to others it may be due to hydration reactions and the addition of rice husk.

performance of composites in which it was inserted as well as the rice husk obtained satisfactory results for use in rural constructions.

scholarship by CNPq and São Paulo's Agency for Agribusiness Technology (APTA) for providing the swine deep bedding.

Braz.) [online]. 2008, vol.65, n.2 ISSN 0103-9016. Accessed Sep. 04, 2013. HIGARASHI, M. M.; COLDEBELLA, A.; OLIVEIRA, P. A. V.; KUNZ, A.; MATTEI, R. M.; SILVA, V. S.; AMARAL, A. L. Macronutrients and heavy metals shavings unit of pigs in deep bedding. Revista Brasileira de Engenharia Agrícola e ambiental, v.12, n.3, p.311-317, 2008.

LUZ, C. A.; CHERIAF, M.; ROCHA, J. C.; AMBROISE, J.; PÊRA, $\mathrm{J}$. Formulation and Application of a cement Low Environmental Impact 
Assessment (BIA) Obtained by phosphogypsum Recycled and with Sulfo-aluminate Clinker. Revista Matéria, v. 10, n. 3, pp. $392-412$, 2005.

MARTINEZ R. G. Placas PréMoldadas de Argamassa Armada e Casca de Arroz. 2003. 96f. Dissertação (Mestrado) - Centro de Ciências e Tecnologia, Universidade Federal de Campina Grande, Campina Grande - PB, 2003. OLIVEIRA, RODRIGUES, M. S.; SANTOS, S. F.; SAVASTANO JUNIOR, $\mathrm{H}$. Characterization and use of swine deep bedding ashes in cementitious composites. Engenharia

Agrícola, Jaboticabal, v. 32, n. 5, Oct. 2012 . Available from $<$ http://www.scielo.br/scielo.php?script =sci_arttext\&pid $=S 0100691620120005$ $0-0001 \&$-Ing=en\&nrm=iso>. Accessed July 12, 2013.

OLIVEIRA, P. A. V. DE. Comparasion dês systèmes d"elevage dês porcs sur litière de sciure ou caillebotis integral. Thèse de docteur, no: 9-4, D-2, L' Ensa de Rennes, France, 272 p., 1999.

RILEM TECHNICAL COMMITTE 49 - TFR Draft Recommendations. Matériaux et Constructions. Vol. 17, n. 102, p.441456, 1984.

TONOLI, G. H. D.; JOAQUIM, A. P.; ARSĖÈNE, M. A.; BILBA, K.; SAVASTANO JR, $H$. Performance and durability of cement based composites reinforced with refined sisal pulp. Materials and Manufacturing Processes, v.22, p.149-156, 2007. 